\section{Proximity of residence to an old mineral storage site in Chile and blood lead levels in children}

\author{
Proximidad residencial con un viejo depósito \\ mineral en Chile y el nivel de plomo en \\ sangre de niños
}

\author{
Proximidade residencial com um velho depósito \\ mineral no Chile e nível de chumbo no \\ sangue em crianças
}

\begin{abstract}
Evidence suggests that an old mineral storage site removed in 1998 due to high lead content, remains as a source of exposure in the city of Antofagasta, Chile. The aim was to determine the association between blood lead levels in children and the residential proximity to the old mineral storage site. A cross sectional study was conducted with 185 children aged 7 to 16 years. The outcome variable was blood lead levels measured in 2005. The exposure variable was the distance between the current residence and the old mineral storage site. The distance was measured in meters by Geographic Information System (GIS). The median blood lead level in 2005

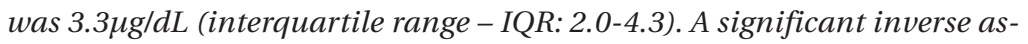
sociation was found between the residential distance to the old mineral storage site and the blood lead levels in children, after adjusting by confounders ( $\beta$ :-0.04; 95\%CI:-0.09; -0.01). This result suggests that the old mineral storage site continues to be a source of lead exposure for the children living nearby.
\end{abstract}

Lead; Environmental Exposure; Child; Geographic Information Systems
Loreto Lisboa 1

José Klarián 2

Rosario Toro Campos ${ }^{3}$

Verónica Iglesias ${ }^{3}$

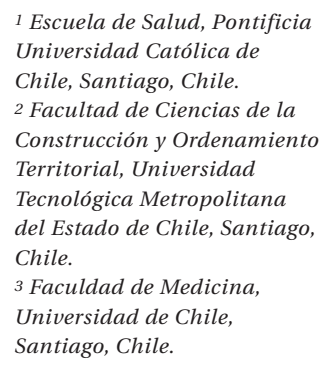

\author{
Correspondence \\ V. Iglesias \\ Escuela de Salud Pública, \\ Faculdad de Medicina \\ Universidad de Chile. \\ Independencia 939, Santiago, \\ Región Metropolitana \\ 8380453, Chile. \\ viglesia@med.uchile.cl
}




\section{Introduction}

Lead exposure causes detrimental health effects, especially among susceptible populations 1 . Exposure to lead is associated with multiple sources (batteries, industrial processes, paint, water pipes, welding, and gasoline) and pathways (dust, soil, food, and air) 2. The main route of absorption in children is digestive, due to their hand-to-mouth behavior, making house dust and soil important sources of exposure ${ }^{3}$. Lead is broadly distributed in the environment; its natural concentration in soil is less than 50ppm 4 . However, in areas near mining and smelting sites, soil lead levels can range between 100 and $11,000 \mathrm{ppm}$. The severity of soil pollution depends on multiple factors including weather, topography, and the specific industrial production 5,6,7. Studies have shown that blood lead levels in children are related to soil lead concentration $8,9,10$. For each 1,000ppm of lead concentration in the soil, the blood lead level typically increases 3-7 $\mu \mathrm{g} / \mathrm{dL} 4,11$.

Antofagasta is a flat coastal city located in the north of Chile. For decades, Antofagasta has been the shipping port for minerals with lead content which come from Bolivia by railroad. The combination of uncovered mineral storage and the location of densely populated areas nearby has resulted in high exposure to lead through soil and air contamination among children living near the storage site 12 . In 1998, children living $400 \mathrm{~m}$ around the mineral storage site at the railroad yard were evaluated for blood lead. The median blood lead level concentration was $8.7 \mu \mathrm{g} / \mathrm{dL}$ (range 1 to $42 \mu \mathrm{g} / \mathrm{dL}$ ) and the main risk factor of having blood lead levels greater than $7.0 \mu \mathrm{g} / \mathrm{dL}$ was living less than $400 \mathrm{~m}$ from the mineral storage site [odds ratio (OR) 24.85; 95\% confidence interval (95\%CI) 5.5-112.1] 13 .

Based on this data, at the end of 1998, Antofagasta's Health Service took measures to reduce exposure, including relocation of the storage site to a less populated area, an educational campaign focused on preventive measures in residential areas, and removal of a layer of soil in the houses nearest to the mineral storage site 13 . After these measures, no samples of soil or blood were collected to determine lead levels. Therefore, the effectiveness of the measures implemented by the Antofagasta Health Service is unknown.

In $2005,44 \%$ of the 1998 cohort was re-evaluated $(n=192)$. In this sample $(n=192)$ it was reported that $33.8 \%(n=65)$ had changed their residence within the urban area of Antofagasta after 1998 14. The results showed a median blood lead level of $3.2 \mu \mathrm{g} / \mathrm{dL}$ (interquartile range - IQR:

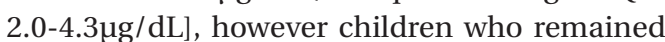

living in the same addresses had greater blood

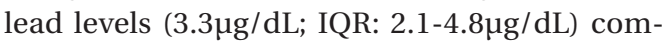
pared with children who moved after $1998(2.9 \mu \mathrm{g} /$

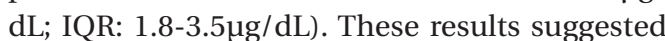
that the old mineral storage site was still a source of lead exposure. To test this hypothesis we conducted a new study to determine the association between children's blood lead levels measured in 2005 and residential proximity to the old mineral storage site.

\section{Materials and methods}

\section{Design and study population}

This is a cross-sectional study that was conducted in 2008 to determine the association between children's blood lead level measured in 2005 and the distance from the children's residence to the old mineral storage site in 2005. The study sample was restricted to children who participated in the 2005 study. These children in 1998 lived within $400 \mathrm{~m}$ of the mineral storage site. In 2005, the Antofagasta Health Service provided us with the names, addresses, and blood lead levels of children who participated in the 1998 study. We visited them, and we were able to locate and enroll 192 children 14 . Of these, 7 were excluded from this analysis because their addresses were not successfully geocoded in the map.

\section{Outcome variable}

The outcome variable was the blood lead concentration measured in 2005. The sample collection method has been detailed elsewhere 14 . Briefly, blood samples were collected by a trained nurse via a finger-prick. Samples were stored at $4^{\circ} \mathrm{C}$ and were sent to the laboratory of environmental chemistry of the Metropolitan Health Service. Samples were analyzed within 48 hours by Anodic stripping voltammetry technique (ESA Laboratories, Chelmsford, USA), a method used in previous studies 9,15,16,17,18,19. This technique uses a device which measure blood lead concentrations between 1 to $65 \mu \mathrm{g} / \mathrm{dL}$ and was previously validated in Chile obtaining a correlation coefficient of 0.82 compared with the gold standard 20 .

\section{Exposure variable}

The exposure variable was the distance between the children's address registered in 2005 and the old mineral storage site. To assess the distance, the area of storage site was identified through a photogrammetric model in a 1:5,000 scale. Using 
a Geographic Information System (GIS), the area was geocoded and its surface and central point were determined. The 185 residential addresses for each child were geocoded as well. Finally, the distance (meters) between the central point of the storage site and each residential addresses were estimated (Figure 1).
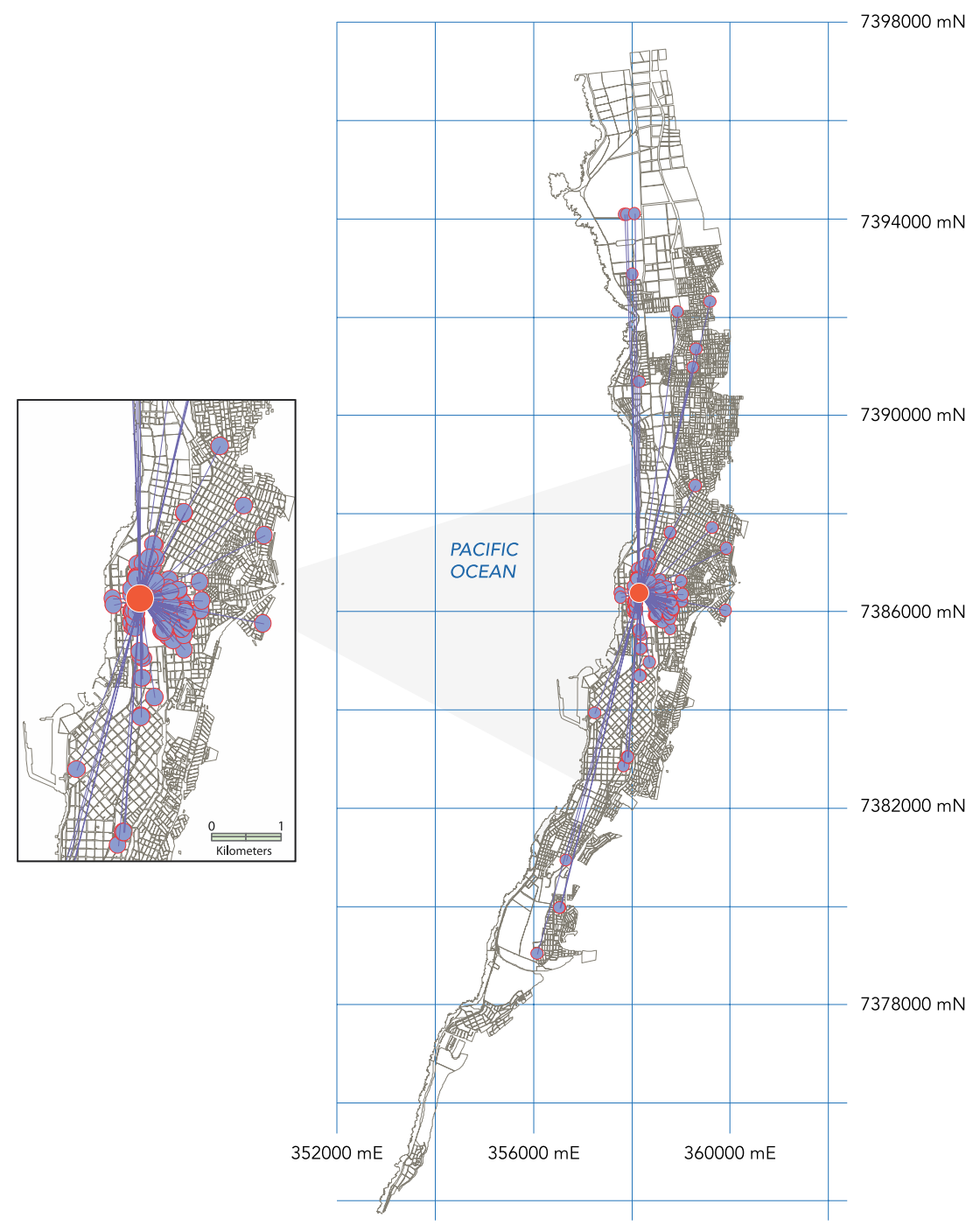

Lead storage site

Distance between houses and the lead storage site

- Samples spatial distribution for children under 16 years old

$0 \quad 1 \quad 2$ Kilometers
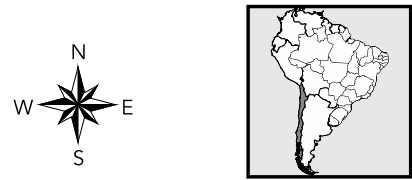


\section{Covariates}

Information about covariates was obtained through a questionnaire given to the parents in 2005. Information collected included data on age, sex, maternal education, number of household members, number of siblings, ownership of household items, home ownership, type of school attended by the children and change of residence after 1998 .

\section{Environmental samples}

In order to explore soil and dust lead concentrations near to the old mineral storage site, we collected soil $(n=13)$ and dust samples $(n=13)$. The samples were taken in three concentric rings circling the old mineral storage location. These rings included an internal one $200 \mathrm{~m}$ from the storage site, a central one $400 \mathrm{~m}$ from the site storage, and an external one $600 \mathrm{~m}$ from the site. Additionally, two control samples (of soil and dust) were collected outside the urban area of Antofagasta, where the concentration of lead was assumed not to be associated with the old mineral storage site. The soil samples were taken in a demarcated area of $1 \mathrm{~m}^{2}$. A clean steel shovel was used to extract $2 \mathrm{~cm}$ of superficial soil that was then deposited in a plastic container. The soil was then mixed and a $300 \mathrm{~g}$ sample was taken from the mixture. Dust samples were taken from the roof of the residence where precipitated dust tends to accumulate. Both types of samples were stored in plastic and hermetic bags and protected from sunlight and humidity. Lead levels in the environmental samples were measured by an inductively coupled plasma atomic emission spectroscopy (ICP-AES) technique in the Geochemical Laboratory of the Geology Department of University of Chile.

\section{$\underline{\text { Statistical analysis }}$}

The main outcome variable was blood lead levels in 2005; these were log-transformed for normality. Simple and multiple linear regression models were fitted for blood lead levels and the distance between the children's residential address and the old mineral storage site, with distance used as the continuous variable. The variables associated with blood lead levels with a p-value $\leq 0.05$, were retained for the final model; these included age, sex, blood lead levels in 1998 and maternal education (years). Blood lead levels in 1998 were included because we wished to determine whether distance from the 2005 residence to the storage site was still associated with blood lead levels in 2005, after taking into account levels at the time the storage site was moved in 1998.
Regression diagnostics to evaluate multicollinearity, homoscedasticity and normality of residuals were explored in fitting the final multivariate models. Multicollinearity between the predictor variables was assessed by using the variance inflation factor (VIF), and was absent in final models. Homoscedasticity was determined by the White test 21 and showed that the variance of residuals were constant. Finally, assessment of distribution of residuals demonstrated a normal distribution. Analyses of the data were performed using Stata 10.0 statistical software (StataCorp LP, College Station, USA).

The study was approved by the Ethics Research Committee of the Faculty of Medicine at the University of Chile.

\section{Results}

The median age of the study subjects was 12 years in 2005, and the proportion of male and female participants were roughly the same. The majority of subjects attended public schools (58.7\%). All parents had an education of over 12 years; and a high proportion of the families (51\%) were homeowners (Table 1).

In $2005,67.6 \%$ of the study sample lived in the same residential addresses registered in 1998 (Table 1) and among those who changed their residential addresses $(n=60) 10 \%$ reported that the main reason for moving was to decrease their lead exposure.

\section{Blood lead levels and demographic covariates}

The children who participated in the study ( $\mathrm{n}=$ 185) had a median blood lead level of $3.3 \mu \mathrm{g} / \mathrm{dL}$ (2.0-4.3) in 2005. Lower blood lead levels were observed in girls compared to boys, in older children, in children who attended private schools compared to those who attended public schools, in children of mothers with lower level of education, and in children who had moved from their houses after $1998(3.0 \mu \mathrm{g} / \mathrm{dL})$ compared to those who remained living in the same place $(3.4 \mu \mathrm{g} /$ dL) (Table 2).

\section{Distance}

The median distance between the central point of the storage site and each of the 185 residential addresses was 572.6 meters (IQR: 340.8-1,036.5). Within the group who changed their residential address $(n=60)$, the median distance between the new residence and the storage site was 2,041 meters (IQR: 460.5-4,731.2). On the other hand, 
Children's and families' characteristics.

\begin{tabular}{|c|c|c|c|}
\hline & Median & IQR & $\%$ \\
\hline Age & 12 & $10-13$ & \\
\hline \multicolumn{4}{|l|}{ Sex } \\
\hline Female & & & 48.1 \\
\hline Male & & & 51.9 \\
\hline \multicolumn{4}{|l|}{ School } \\
\hline Public & & & 58.7 \\
\hline Private & & & 41.3 \\
\hline \multicolumn{4}{|l|}{ Marital status of mother } \\
\hline Single & & & 21.4 \\
\hline Married & & & 60.3 \\
\hline Living with a partner & & & 7.2 \\
\hline Widow & & & 9.5 \\
\hline Other & & & 1.6 \\
\hline Maternal education (years) & 12.5 & $12-15$ & \\
\hline Paternal education (years) & 14.0 & $12-16$ & \\
\hline \multicolumn{4}{|l|}{ Home ownership } \\
\hline Owner & & & 51.1 \\
\hline Rent & & & 16.5 \\
\hline Staying with relatives & & & 28.0 \\
\hline Other & & & 4.4 \\
\hline \multicolumn{4}{|l|}{ Change of residence after 1998} \\
\hline Yes & & & 32.4 \\
\hline No & & & 67.6 \\
\hline Household income (USD) & 653 & $327-1,203$ & \\
\hline Number of household members & 5 & $4-5$ & \\
\hline
\end{tabular}

IQR: interquartile range.

the median distance in the group who remained living in the same residence as in $1998(\mathrm{n}=125)$ was 465.1m (IQR: 284.4-664.4).

\section{Association between blood lead levels and distance}

Simple linear regression models were used to identify the variables related with blood lead levels in 2005. In the crude analysis an inverse and significant association was identified between the blood lead levels in 2005 and the residential distance to the old mineral storage site (Table 3 ). The $2.5 \%$ of the variance of blood lead levels measured in 2005 correspond to distance. Sex, age, blood lead levels in 1998, maternal education, number of household members, ownership of household items, home ownership, and type of school attended by the children were the variables that showed a statistically significant association with the blood lead level in 2005 ( $\mathrm{p}$-value < 0.05). Because the variables measuring socioeconomic status were closely related $(p$-value $=0.0001)$, we chose to use only maternal education (the strongest predictor among the socioeconomic variables) as a proxy of socioeconomic status. Thus, in the final model the variables included were residential distance to the old mineral storage site, age, sex, blood lead levels in 1998, and maternal education. An inverse and significant association was identified between the blood lead levels in 2005 and the residential distance in meters to the old mineral storage site $(\beta=-0.04$; $\mathrm{p}$-value $=0.042)($ Table 3$)$. The variables included in the model together explain $29 \%$ of the variance of blood lead levels measured in 2005.

\section{Environmental samples}

As noted above, soil and dust samples were geocoded in concentric three ring formations circling the old mineral storage site, with the aim of exploring soil and dust lead concentrations related to the potential residual pollution of the 
Descriptive analyses of blood lead level $(\mu \mathrm{g} / \mathrm{dL})$ and sociodemographic variables.

\begin{tabular}{|c|c|c|c|c|}
\hline Variable & Median & IQR & Minimum & Maximum \\
\hline \multicolumn{5}{|l|}{ Sex } \\
\hline Male & 3.5 & $2.4-5.0$ & 1.0 & 13.2 \\
\hline Female & 2.4 & $1.7-3.7$ & 0.5 & 14.0 \\
\hline \multicolumn{5}{|l|}{ Age (years) } \\
\hline $5-11$ & 3.2 & $2.0-4.5$ & 0.8 & 14.0 \\
\hline $12-16$ & 3.4 & $2.1-4.3$ & 0.6 & 13.2 \\
\hline \multicolumn{5}{|l|}{ School } \\
\hline Public & 3.5 & $2.4-5.0$ & 0.5 & 14.0 \\
\hline Private & 2.3 & $1.6-3.4$ & 0.6 & 6.8 \\
\hline \multicolumn{5}{|c|}{ Maternal education (years) } \\
\hline $5-10$ & 4.8 & $3.6-6.2$ & 1.2 & 13.2 \\
\hline $11-15$ & 3.1 & $2.0-3.8$ & 0.5 & 10.6 \\
\hline $16-23$ & 3.0 & $1.8-5.0$ & 1.0 & 14.0 \\
\hline \multirow{2}{*}{\multicolumn{5}{|c|}{$\begin{array}{l}\text { Blood lead level in } 2005 \text { if change of residence } \\
\text { after } 1998\end{array}$}} \\
\hline & & & & \\
\hline No & 3.4 & $2.1-4.8$ & 0.5 & 14.0 \\
\hline Yes & 3.0 & $1.8-3.5$ & 0.6 & 10.6 \\
\hline
\end{tabular}

IQR: interquartile range.

Table 3

Association between blood lead levels $(\mu \mathrm{g} / \mathrm{dL})$ and distance between residence and the old mineral storage site in children aged $7-16$ years

\begin{tabular}{|c|c|c|}
\hline Variable & $B \pm S E$ & $95 \% \mathrm{Cl}$ \\
\hline Distance (crude analysis) & $-0.05 \pm 0.02$ & $-0.10 ; 0.005$ \\
\hline Distance (multivariable analysis) * & $-0.04 \pm 0.02$ & $-0.09 ; 0.010$ \\
\hline
\end{tabular}

95\% $\mathrm{Cl}$ : 95\% confidence interval; SE: standard error.

* Variables included in the multiple linear regression model: age, sex, blood lead levels in 1998 and maternal education (years).

environment. The median of the dust samples was 1,300ppm (IQR: 637-1,600), with a minimum of $173 \mathrm{ppm}$ and a maximum of $3,758 \mathrm{ppm}$. $54 \%$ of the samples $(n=7)$ evaluated exceeded the international norm of $1,200 \mathrm{ppm}$ in precipitated dust 22 . The samples of soil showed a median of 132ppm (IQR: $88-227$ ), with a minimum of $57 \mathrm{ppm}$ and a maximum of $1,006 \mathrm{ppm}$. $15.4 \%$ of the samples $(n=2)$ exceeded the international norm of 400 ppm in soil 22. A relationship between lead concentration and the distance to the old mineral storage site was observed. Lower lead concentrations were found in dust and soil samples at greater distances (Table 4). The median lead concentration in the dust samples was more than nine times greater than the concentration found in the control samples, while for the soil samples it was three times higher.

\section{Discussion}

These results, based on soil and dust samples, clearly indicate that the area surrounding the old mineral storage site is still contaminated with lead. $54 \%$ of dust samples exceeded the international norms of $1,200 p p m$ and $15.4 \%$ of soil samples exceeded the international norm of 400 ppm 22. For both cases, a decreasing lead level was found as the samples were taken further from the old mineral storage site. 
Lead concentration (ppm) in dust and soil samples in relation to proximity to the old mineral storage site.

\begin{tabular}{lcccc}
\hline Type of sample & Within 200m & Between 201 m and 400m & Between 401m and 600m & Control sample \\
\hline Dust & $1,386(878-3,758)$ & $974(285-1716)$ & $786(637-934)$ & 141 \\
Soil & $227(79-1,006)$ & $162.8(59-386)$ & $117(57-177)$ & 39 \\
\hline
\end{tabular}

These results are consistent with studies reporting that when lead falls into the soil, it strongly sticks to the soil particles and is retained in the most superficial portion of soil. The lead then remains in the environment due to its properties of non-biodegradation 4,5,6,23. Moreover, the weather conditions in Antofagasta may increase the persistence of lead because the mean annual precipitation is less than $5 \mathrm{~mm}$, preventing the upper soil from being washed away.

We found that, even after removal of the lead storage in 1998, and adjusting for children's blood lead in 1998, distance from the old storage sites was inversely and significantly associated with children's blood lead measured in 2005. These results indicate that the lead exposure continued in children after removal of the storage site, presumably from soil and dust. The results in the present research correspond with a number of studies carried out previously 6,8,18. However, those studies are of lead sources with ongoing exposure, in contrast to our study that shows that even after the removal of the source of exposure, exposure continues. One of these studies, conducted in North Lake Macquarie, Australia, used the same GIS procedure to correlate blood lead levels with the distance of a lead contaminated source (a foundry). The study reported the presence of an inverse and significant relationship between blood lead level in children aged 1 to 3 and the distance to the foundry. A blood lead level decrease of $3.08 \mu \mathrm{g} / \mathrm{dL}$ was estimated for each kilometer of distance from the foundry ${ }^{8}$. Similar results regarding distance from a lead source were found in the metropolitan areas of Callao and Lima, Peru 18.

Other studies have shown that even without a point source of lead pollution, exposure is related to dust lead levels, as in the research conducted by Lanphear et al. 19 in Cincinnati, Ohio, United States. In the latter, the research team evaluated indoor lead pollution and blood lead levels in children aged 12 to 31 months. These authors indicated that lead-contaminating floor dust, rental status and housing conditions were housing characteristics that were associated with blood lead levels higher than 10 $\mathrm{\mu g} / \mathrm{dL} 19$.

The results of our study show that, although mitigation measures conducted by the health authorities after 1998 were able to reduce lead exposure, they were probably not enough. Further studies measuring soil and blood samples in children born after removal of the storage site may have helped to identify if lead exposure was still present.

\section{Study limitations}

In our study, the residential distribution was not representative; as shown in Figure 1, most of the sample lived near the storage site. A random selection of the study population would have been preferable. Nonetheless, despite the low variability in the distance, an inverse and significant association was found between blood lead levels and the residential distance to the old mineral storage site. A second limitation is the age of the subjects. Children in our study had a median age of 12 years with a range of 7 to 16 years. The literature has shown that at younger ages (2-4 years old), children have an increased risk of higher blood lead concentration mainly due to physiological and behavioral factors 16 . Once lead enters the body, children absorb more of it, attaining higher blood lead levels compared with adults with the same ingestion. Considering this physiologic susceptibility, it is possible that the inclusion of younger children in new studies could raise the median blood lead concentration found in the study. If this were the case, it is unlikely that the magnitude of the association between blood lead level measured in 2005 and distance to the old mineral storage site would have changed.

Time of exposure is another factor to consider. While blood lead levels have shown to be a good biomarker of short term exposure, some studies describe the auto-intoxication created by the endogenous release of lead from bones 16 . This suggests that current blood lead concentration may in part be due to osteolysis in 
addition to environmental exposure. Although we adjusted for blood lead levels in 1998, it might have been preferable to evaluate a sample with children born after 1998, which could help to distinguish between later exposure and exposure before removal from the storage site.

\section{Strengths}

A particular strength is the use of GIS as a tool applied to epidemiology, which at the time of the study had been little used in Chile. The use of this methodology allowed us to measure the exposure variable (distance) more accurately and identify a range of possible values. This makes it possible to diminish misclassification bias that would result from the use of a dichotomous exposure variable such as change of address. In fact the relationship between blood lead concentration in 2005 and change of address was not significant ( $p$-value $=0.127$ ) whereas with distance was significant $(\mathrm{p}$-value $=0.029$ ).

\section{Contributors}

L. Lisboa and V. Iglesias contributed on the conception of the project, data analysis and interpretation, writing up of the manuscript, critical review and final approval of the final version. J. Klarián and R. T. Campos participated on data analysis and interpretation, critical review and final approval of the final version.

\section{Conclusions}

The present study shows an inverse association between blood lead levels in 2005 and the distance between the housing and the mineral storage site where lead was stored before 1998. This association, together with the result of the environmental samples, indicates that this zone is still a source of lead exposure. New studies need to be conducted to evaluate the current blood lead levels in children born after the mineral storage site was removed in 1998. In addition, an environmental study should be conducted to evaluate possible new measures such as cleaning the contaminated zone as well as houses surrounding the old mineral storage site.

\section{Acknowledgments}

We wish to acknowledge the support of A. Hanchey and B. Baumert for their assistance in reviewing and editing the manuscript and the families who kindly agreed to participate in this study. 


\section{References}

1. Koller K, Brown T, Spurgeon A, Levy L. Recent developments in low-level lead exposure and intellectual impairment in children. Environ Health Perspect 2004; 112:987-94.

2. Romieu I. Uso de los datos de plumbemia para evaluar y prevenir el envenenamiento infantil por plomo en Latinoamérica. Salud Pública Méx 2003; 45 Suppl 2:S244-51.

3. Tong S, von Schirnding YE, Prapamontol T. Environmental lead exposure: a public health problem of global dimensions. Bull World Health Organ 2000; 78:1068-77.

4. Centers for Disease Control and Prevention. Impact of lead-contaminated soil on public health. http://wonder.cdc.gov/wonder/pre vguid/p0000015/p0000015.asp (accessed on 05/ Nov/2014).

5. Agency for Toxic Substances and Disease Registry. Toxicological profile for lead. http://www.atsdr. cdc.gov/toxprofiles/tp13.pdf (accessed on 05/ Nov/2014).

6. Cala V, Kunimine Y. Distribución de plomo en suelos contaminados en el entorno de una planta de reciclaje de baterías ácidas. Revista Internacional de Contaminación Ambiental 2003; 19:109-15.

7. Díaz Barriga F, Corey Orellana G. Evaluación del riessgo por la exposición a plomo. http://www. bvsde.paho.org/bvsea/e/fulltext/plomo/plom. html (accessed on 10/Nov/2014).

8. Willmore A, Sladden T, Bates L, Dalton C. Use of a geographic information system to track smelter-related lead exposures in children: North Lake Macquarie, Australia, 1991-2002. Int J Health Geogr 2006; 5:30.

9. Zahran S, Mielke HW, Weiler S, Gonzales CR. Nonlinear associations between blood lead in children, age of child, and quantity of soil lead in metropolitan New Orleans. Sci Total Environ 2011; 409: 1211-8.

10. Mielke HW, Gonzales CR, Powell E, Jartun M, Mielke PW. Nonlinear association between soil lead and blood lead of children in metropolitan New Orleans, Louisiana: 2000-2005. Sci Total Environ 2007; 388:43-53

11. Madhavan S, Rosenman KD, Shehata T. Lead in soil: recommended maximum permissible levels. Environ Res 1989; 49:136-42.

12. Tchernitchin A, Lapin N, Molina L, Molina G, Tchernitchin N, Acevedo C, et al. Human exposure to lead in Chile. In: Ware G, Nigg H, Doerge D, editors. Reviews of environmental contamination and toxicology. New York: Springer; 2006. p. 93-139.
13. Sepúlveda V, Vega Morales J, Delgado, I. Exposición severa a plomo ambiental en una población infantil de Antofagasta, Chile. Rev Méd Chile 2000; 128:221-32.

14. Iglesias V, Steenland K, Maisonet M, Pino P. Exposure to lead from a storage site associated with intellectual impairment in Chilean children living nearby. Int J Occup Environ Health 2011; 17: 314-21.

15. Agency for Toxic Substances and Disease Registry. Case studies in environmental medicine (CSEM): lead toxicity. http://www.atsdr.cdc.gov/csem/ lead/docs/lead.pdf (accessed on 10/Nov/2014).

16. Barbosa F, Tanus-Santos JE, Gerlach RF, Parsons PJ. A critical review of biomarkers used for monitoring human exposure to lead: advantages, limitations, and future needs. Environ Health Perspect 2005; 113:1669-74.

17. Bellinger DC. Lead. Pediatrics 2004; 113(4 Suppl):1016-22.

18. Espinoza R, Hernández-Avila M, Narciso J, Castañaga C, Moscoso S, Ortiz G, et al. Determinants of blood-lead levels in children in Callao and Lima metropolitan area. Salud Pública Méx 2003; 45 Suppl 2:209-19.

19. Lanphear BP, Hornung R, Ho M. Screening housing to prevent lead toxicity in children. Public Health Rep 2005; 120:305-10.

20. Sánchez-Cortez J, Ilabaca-Marileo M, Martín MA, Viñas ML, Bravo-Méndez R. Prevalencia de plomo en sangre, en niños escolares de Santiago de Chile. Salud Pública Méx 2003; 45 Suppl 2:264-8.

21. White A. A heteroskedasticity-consistent covariance matrix estimator and a direct test for heteroskedasticity. Econometrica 1980; 48:817-38.

22. United States Environmental Protection Agency. Hazard standards for lead in paint, dust and soil (TSCA Section 403). http://www2.epa.gov/lead/ hazard-standards-lead-paint-dust-and-soil-tscasection-403 (accessed on 03/Jun/2015).

23. United States Environmental Protection Agency. Sumary and assessment of published information on determining lead exposures and mitigating lead hazards associated with dust and soil in residential carpets, furniture and forced air ducts. http://www.epa.gov/sites/production/files/docu ments/ls_final.pdf (accessed on 03/Jun/2015). 


\section{Resumen}

Evidencia sugiere que un antiguo sitio de acopio de minerales removido en 1998 por el alto contenido de plomo, aún sería una fuente de exposición en la ciudad de Antofagasta, Chile. El objetivo fue determinar la asociación entre la concentración de plomo en sangre y la distancia entre la vivienda actual y el antiguo sitio de acopio. Se realizó un estudio de diseño transversal con 185 niños de 7 a 16 años. La variable dependiente fue la concentración de plomo sanguíneo, medida el 2005. La variable de exposición fue la distancia entre la vivienda actual y el antiguo sitio de acopio. Esta distancia fue medida en metros mediante Sistema de Información Geográfica (SIG). La concentración de plomo en sangre fue de $3,3 \mu \mathrm{g} / \mathrm{dL}$ (rango intercuartil RIC: 2,0-4,3). Se encontró una relación inversa y significativa entre la distancia de la vivienda al antiguo sitio de acopio y la concentración de plomo sanguíneo ( $\beta$ : -0,04; IC95\%: -0,09; -0,01). Este resultado sugiere que el antiguo sitio de acopio de minerales sigue siendo una fuente de exposición a plomo.

Plomo; Exposición a Riesgos Ambientales; Niño; Sistemas de Información Geográfica

\section{Resumo}

A evidência sugere que um depósito de minerais removido em 1998 por seu alto teor de chumbo ainda poderia ser uma fonte relevante de exposição a este metal, na cidade de Antofagasta, Chile. O objetivo deste trabalho foi determinar a associação entre a distância da residência até o antigo depósito e a concentração de chumbo no sangue. Estudo transversal com 185 crianças de 7-16 anos. A variável dependente foi a concentração de chumbo no sangue medido em 2005; a exposição foi a distância (metros) entre a residência atual e o antigo depósito de chumbo, obtida por meio do Sistema de Informação Geográfica (SIG). A concentração de chumbo no sangue foi de $3,3 \mu \mathrm{g} / \mathrm{dL}$ (intervalo interquartil -IQR:2,0-4.3). Constatou-se uma relação inversa entre a distância da casa para o antigo local de recolha e a concentração de chumbo no sangue ( $\beta$ : -0,04; IC95\%: -0,09; -0,01). Esse resultado confirma que o antigo lugar de armazenagem do minério continua a ser uma fonte relevante de exposição ao chumbo.

Chumbo; Exposição Ambiental; Criança; Sistemas de Informação Geográfica
Submitted on 04/Mar/2015

Final version resubmitted on 22/Aug/2015 Approved on 21/Sep/2015 